\title{
Impact of Systemic Inflammation and Autoimmune Diseases on apoA-I and HDL Plasma Levels and Functions
}

\author{
Fabrizio Montecucco, Elda Favari, Giuseppe Danilo Norata, \\ Nicoletta Ronda, Jerzy-Roch Nofer, and Nicolas Vuilleumier
}

\section{Contents}

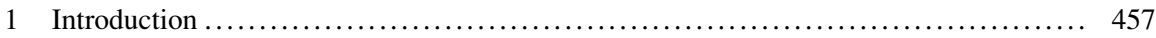

2 HDL/apoA-I Structure and Function ...................................... 458

3 HDL and apoA-I as Members of the Innate Immune System ..................... 459

4 Relationship Between Lipid Raft Modulation and Lymphocyte Function ............ 460

5 Modulation of Spinghosine-1-Phosphate (S1P)/S1P-Receptor Axis and Lymphocyte

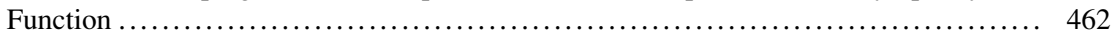

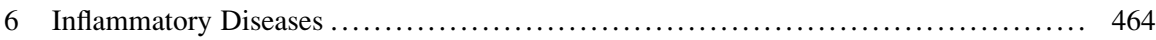

F. Montecucco

Division of Laboratory Medicine, Department of Genetics and Laboratory Medicine,

Geneva University Hospitals, 4 rue Gabrielle Perret-Gentil, 1211 Geneva, Switzerland

Department of Human Protein Science, Geneva, Switzerland

Division of Cardiology, Geneva University Hospital, Geneva, Switzerland

E. Favari • N. Ronda

Department of Pharmacy, University of Parma, Parma, Italy

G.D. Norata

Department of Pharmacological and Biomolecular Sciences, Università degli Studi di Milano, Milan, Italy

Center for the Study of Atherosclerosis, Società Italiana Studio Aterosclerosi,

Ospedale Bassini, Cinisello Balsamo, Italy

The Blizard Institute, Centre for Diabetes, Barts and The London School of Medicine \& Dentistry, Queen Mary University, London, UK

J.-R. Nofer

Center for Laboratory Medicine, University Hospital Münster, Münster, Germany

N. Vuilleumier $(\triangle)$

Division of Laboratory Medicine, Department of Genetics and Laboratory Medicine,

Geneva University Hospitals, 4 rue Gabrielle Perret-Gentil, 1211 Geneva, Switzerland

Department of Human Protein Science, Geneva, Switzerland

e-mail: nicolas.vuilleumier@hcuge.ch

(C) The Author(s) 2015

A. von Eckardstein, D. Kardassis (eds.), High Density Lipoproteins, Handbook of

Experimental Pharmacology 224, DOI 10.1007/978-3-319-09665-0_14 
6.1 Inflammatory Bowel Diseases ..................................... 464

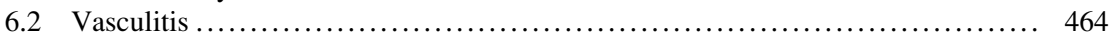

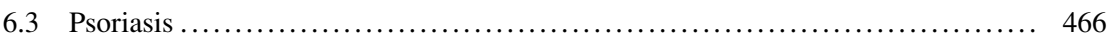

7 Autoimmune Diseases: The Role of Autoantibodies ............................ 467

7.1 Systemic Lupus Erythematosus (SLE) ............................... 467

7.2 Rheumatoid Arthritis (RA) ........................................ 468

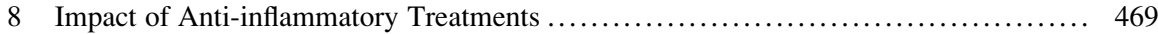

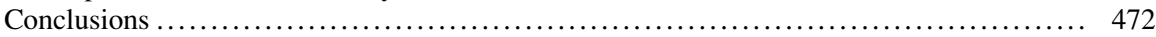

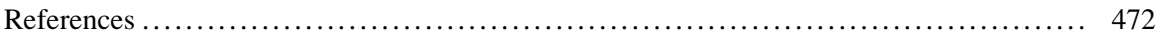

\begin{abstract}
The cholesterol of high-density lipoproteins (HDLs) and its major proteic component, apoA-I, have been widely investigated as potential predictors of acute cardiovascular (CV) events. In particular, HDL cholesterol levels were shown to be inversely and independently associated with the risk of acute CV diseases in different patient populations, including autoimmune and chronic inflammatory disorders. Some relevant and direct anti-inflammatory activities of HDL have been also recently identified targeting both immune and vascular cell subsets. These studies recently highlighted the improvement of HDL function (instead of circulating levels) as a promising treatment strategy to reduce inflammation and associated CV risk in several diseases, such as systemic lupus erythematosus and rheumatoid arthritis. In these diseases, anti-inflammatory treatments targeting HDL function might improve both disease activity and $\mathrm{CV}$ risk. In this narrative review, we will focus on the pathophysiological relevance of HDL and apoA-I levels/functions in different acute and chronic inflammatory pathophysiological conditions.
\end{abstract}

\title{
Keywords
}

Systemic inflammation • Autoimmune disease • apoA-I • HDL • Innate immunity

\section{Abbreviations}

$\begin{array}{ll}\text { ABCA } & \text { ATP-binding cassette transporters } \\ \text { ABCG1 } & \text { ATP-binding cassette G1 } \\ \text { APC } & \text { Antigen-presenting cells } \\ \text { apoA-I } & \text { Apolipoprotein A-1 } \\ \text { APR } & \text { Acute-phase response } \\ \text { BD } & \text { Behçet's disease } \\ \text { CAD } & \text { Coronary artery disease } \\ \text { CD } & \text { Crohn's disease } \\ \text { CVD } & \text { Cardiovascular diseases } \\ \text { EBV } & \text { Epstein-Barr virus } \\ \text { HDL-C } & \text { High-density lipoprotein cholesterol } \\ \text { hs-CRP } & \text { High-sensitivity C-reactive protein }\end{array}$




$\begin{array}{ll}\text { IBD } & \text { Inflammatory bowel diseases } \\ \text { KD } & \text { Kawasaki disease } \\ \text { LPL } & \text { Lipoprotein lipase } \\ \text { Lp-PLA2 } & \text { Lipoprotein-specific phospholipase A2 } \\ \text { LPS } & \text { Lipopolysaccharide } \\ \text { LTA } & \text { Lipoteichoic acid } \\ \text { MPO } & \text { Myeloperoxidase } \\ \text { piHDL } & \text { Proinflammatory HDL } \\ \text { PON1 } & \text { Paraoxonase 1 } \\ \text { RA } & \text { Rheumatoid arthritis } \\ \text { SAA } & \text { Serum amyloid A } \\ \text { SLE } & \text { Systemic lupus erythematosus } \\ \text { SMAD } & \text { Small mothers against decapentaplegic } \\ \text { SR-BI } & \text { Scavenger receptor BI } \\ \text { Th1 } & \text { T helper type 1 } \\ \text { TGF- } \beta & \text { Transforming growth factor beta } \\ \text { UC } & \text { Ulcerative colitis }\end{array}$

\section{$1 \quad$ Introduction}

Since the seminal publication by Miller and coworkers in 1975, HDL-C has consistently been shown to be inversely and independently associated with the risk of acute CVD (such as myocardial infarction) (Miller and Miller 1975; Castelli et al. 1986; Di Angelantonio et al. 2009) and became one of the most commonly measured biomarkers (Expert Panel 2001). Nevertheless, the recent failures of HDL-C-raising therapies to reduce $\mathrm{CV}$ complications and atherosclerosis (Davidson 2012) as well as Mendelian randomization studies to demonstrate associations of genetically determined HDL-C levels with altered CV risk (Voight et al. 2012; Shah et al. 2013; Haase et al. 2012) raised the question whether HDL is an innocent bystander or a mediator of atherogenesis and CVD.

Among the important progresses in our understanding about HDL physiopathology, many studies stress the importance of HDL functions rather than HDL-C blood levels. This in turn could be of key importance to understand the negative outcome of both interventional trials and Mendelian randomization studies which did not take HDL functionality into account. Indeed, there is a growing body of evidence indicating that both acute and chronic inflammatory conditions induce posttranslational modifications of HDL, impairing both its lipid homoeostasis-regulating and anti-inflammatory properties, and even turn HDL into a proinflammatory molecule (Navab et al. 2011).

Those observations are shifting the attention from HDL-C levels to HDL function, emphasizing the importance of taking into account the clinical situations in which HDL-C levels are measured. Therefore, the precise knowledge of the 
different chronic or acute conditions susceptible to affect both the quantity and quality of HDL is likely to be paramount in order to understand the actual controversy about the causal role of HDL in CVD. Furthermore, because many of the functional properties of HDL can be recapitulated by apolipoprotein A-1 (apoA-I) (Phillips 2013), we will review the different acute and chronic inflammatory pathophysiological conditions reported to affect both HDL and apoA-I levels and functions, as potential modulators of the innate immune system.

\section{HDL/apoA-I Structure and Function}

Since HDL structure is predominantly affected by the presence of apoA-I (Phillips 2013), both molecules will be presented in a joint manner. Depending on the lipid state of apolipoproteins, HDL molecules are heterogeneous in shape, size, and density. The predominant HDL species are spherical HDL, consisting of a core of cholesteryl ester (CE) and triacylglycerol, encapsulated by a monolayer of phospholipids, unesterified cholesterol, and different lipoproteins. The latter is mostly represented by apoA-I which constitutes the major protein fraction of HDL and represents up to $80 \%$ of HDL mass (Heinecke 2009). The second more abundant lipoprotein of HDL is apoA-II, followed by less abundant proteins including apoCs, D, E, J, and M; several enzymes such as lecithin-cholesterol acyltransferase (LCAT), serum paraoxonase 1 (PON1), and platelet-activating factor acetylhydrolase (PAF-AH); and sphingosine-1-phosphate (S1P) (see chapter "Structure of HDL: Particle Subclasses and Molecular Components" for more details).

The atheroprotective role of HDL on the cardiovascular system has been attributed to the pleiotropic effects of HDL, including reverse cholesterol transport, vasodilatation, antithrombotic, anticoagulant, and anti-inflammatory effects (Gordon and Davidson 2012). Reflecting those versatile properties, mass spectrometry analyses revealed that HDL encompasses up to 80 different proteins. Two-thirds of them are either acute-phase proteins, proteases, antioxidants, antithrombotic enzymes, or proteins involved in complement regulation, and only one-third are dedicated to lipid transport (Heinecke 2009).

On top of being the major protein fraction of HDL and a limiting factor for HDL formation, apoA-I per se executes many of the HDL-related properties, ranging from reverse cholesterol efflux and LPS and LTA scavenging to the inhibition of different proinflammatory, pro-oxidant, and prothrombotic pathways (Gu et al. 2000; Thuahnai et al. 2003; Yuhanna et al. 2001; Vuilleumier et al. 2013). Thus, HDL and apoA-I appear to contribute to host defense against many biological and chemical hazards. Nevertheless, chronic or acute inflammation induces major changes in HDL-C levels and functions, compromising and perverting the protective activities of HDL to harm.

Infection and inflammation generate an acute-phase response (APR), leading to important changes affecting the metabolism of different lipids and lipoproteins and thereby resulting in increased plasma levels of triglycerides and very-low-density 
lipoprotein (VLDL) cholesterol (reviewed in Khovidhunkit et al. 2004). Concomitantly, the APR also induces major changes in HDL functions since in this context apoA-I is replaced by other acute-phase proteins, such as SAA protein, ceruloplasmin, and haptoglobin (Navab et al. 2011), with SAA representing up to $87 \%$ of HDL proteins and transforming HDL into a proinflammatory molecule (Van Lenten et al. 1995). Furthermore, recent evidence suggests that APR can also induce specific posttranslational modifications, such as chlorination, nitration, and carbamylation of amino acids by myeloperoxidase (MPO), oxidation by reactive carbonyls, as well as glycation, which compromise HDL and apoA-I functions, perverting them to harm (Vuilleumier et al. 2013).

\section{HDL and apoA-I as Members of the Innate Immune System}

The innate immune system represents the first line of defense against infectious agents and modified self-antigens (modified/oxidized lipids and apoptotic cells) consisting of a cellular and a humoral part. Cellular components are represented mostly by antigen-presenting cells (APCs), such as macrophages and dendritic cells, whereas the humoral counterpart is mostly represented by the pentraxin family and the complement system. Being extensively conserved throughout the evolution, and existing in early evolutionary species not affected by CVD (Babin et al. 1997), HDLs are believed to be part of the humoral innate immune system, helping mammals to fight against invading pathogens. Indeed, thanks to the presence of different proteins on HDL molecules, such as apoA-I, apoL-1, and haptoglobin-related proteins, HDLs are known to behave as antimicrobial agents protecting mammals against different parasites and bacteria, such as Trypanosoma brucei, Escherichia coli, and Klebsiella pneumoniae (Shiflett et al. 2005; Beck et al. 2013) (see chapter "HDL in Infectious Diseases and Sepsis").

Furthermore, on top of interfering directly with invading pathogens, HDL and apoA-I also modulate the APR-induced activation of the innate immune system by both neutralizing major bacterial membrane components, such as LPS of Gramnegative bacteria and LTA of Gram-positive bacteria, and modulating the proinflammatory signaling at the level of innate receptors, such as Toll-like receptors (TLRs), scavenger receptors (SRs), and Nod-like receptors (NLRs). Mathison and colleagues demonstrated for the first time in 1979 that HDL could reduce LPS toxicity in vivo (Mathison and Ulevitch 1979). This observation was subsequently inferred to the ability of HDL to sequester LPS, preventing the latter to elicit a proinflammatory response through TLR4/CD14 complex interaction (Levine et al. 1993). Later on, this scavenging effect of HDL was attributed to a specific apoA-I region on the N-terminal segment of apoA-I (aa: 52-74) (Wang et al. 2008). More recently, apoA-I was shown to have a similar ability to bind to LTA and to neutralize its proinflammatory effect (Jiao and Wu 2008). Interestingly, this effect was much weaker with HDL, suggesting that apoA-I is the key effector of 
LTA scavenging (Grunfeld et al. 1999). The integrity of innate immune receptor signaling is largely dependent on their localization into lipid rafts, as well as on the integrity of the latter (Triantafilou et al. 2002). In this respect, apoA-I has been shown to deplete cholesterol from lipid rafts, leading to a decrease in TLR4 functionality, followed by an inhibition of LPS-induced inflammatory responses (Triantafilou et al. 2002). In the same line of thought, on top of altering the lipid raft composition, apoA-I has also been shown to impede TLR4 transport into lipid rafts, thereby preventing its ability to promote an efficient proinflammatory response (Smythies et al. 2010; Cheng et al. 2012). These findings indicate that apoA-I and HDL, albeit to a lesser extent, can effectively modulate TLR activity at the preceptor, receptor, and post-receptor levels (De Nardo et al. 2014).

\section{$4 \quad$ Relationship Between Lipid Raft Modulation and Lymphocyte Function}

Adaptive immune response relies on the activation of lymphocytes and the expansion of specific subsets in response to antigens. B lymphocytes represent an essential component of the humoral adaptive response through the synthesis of immunoglobulins, while $\mathrm{T}$ lymphocytes play a central role in cell-mediated immunity, and indeed the different $\mathrm{T}$ phenotypes orchestrate the immune response through different mechanisms. Two main aspects suggest a link between lipoproteins and adaptive immunity: first, the key receptors of $\mathrm{B}$ and $\mathrm{T}$ cells (BCR and TCR, respectively) are located in the lipid rafts, and their activity is modulated upon changes in the lipid raft composition and structure (Gupta and DeFranco 2007; Kabouridis and Jury 2008; Norata et al. 2012); second, B- and T-cell trafficking and T-cell subset differentiation are controlled also by lysosphingolipids, mainly S1P (Mandala et al. 2002; Liu et al. 2010). Lipid rafts, which concentrate specific proteins, thus limiting their ability to freely diffuse over the plasma membrane, act as platforms, bringing together molecules essential for the activation of immune cells (immunological synapse), but also separating such molecules when the conditions for activation are not appropriate (Ehrenstein et al. 2005). Lipid rafts compartmentalize key signaling molecules during the different stages of B-cell activation including BCR-initiated signal transduction, endocytosis of BCR-antigen complexes, loading of antigenic peptides onto MHC class II molecules, MHC-II-associated antigen presentation to T cells, and receipt of helper signals via the CD40 receptor (Gupta and DeFranco 2007). Critical regulators of $\mathrm{BCR}$ signaling lose their association with membrane rafts in disease conditions; for instance, the LMP2A gene product of the EBV constitutively resides in membrane raft of EBV-transformed human $\mathrm{B}$ cells and blocks the entry of ligand-clustered BCRs and BCR translocation (Longnecker and Miller 1996). Furthermore, an alteration of Lyn, an accessory protein of BCR signaling, has been reported in patients with systemic lupus erythematosus (SLE) (Flores-Borja 
et al. 2005). It is therefore reasonable to speculate that HDL, by removing cholesterol from lipid rafts, could affect B-cell function. While a direct evidence for HDL effects on B-cell function is still lacking, several reports indicate that HDL and apoA-I stimulate cholesterol efflux from cells, leading to cholesterol depletion and disruption of lipid rafts, which induces profound functional changes (Smythies et al. 2010) in macrophages and also affects antigen presentation and TCR signaling (Gruaz et al. 2010; Norata and Catapano 2012).

The response of $\mathrm{T}$ lymphocytes to antigen is orchestrated by a number of molecules that cluster in lipid rafts. TCR complex integrity is vital for the induction of optimal and efficient immune responses (Baniyash 2004). In immune-mediated disorders, such as rheumatoid arthritis (RA) and SLE, and in chronic infectious diseases, $\mathrm{T}$ cells are dysfunctional with a characteristic loss of expression of the TCR $\zeta$ chain (also called CD249), a key component of the TCR complex that couples surface antigen recognition with intracellular signal transduction (Baniyash 2004). Also other molecules associated with the TCR signaling are reduced or altered in autoimmune disorders, such as lymphocyte-specific protein tyrosine kinase (Lck) (Jury et al. 2006). T-cell immunological synapses are altered in circulating $\mathrm{T}$ cells from patients with coronary artery disease (CAD), and increased memory T-cell subsets were observed in particular in CAD patients with increased inflammatory markers (Ammirati et al. 2012a, b). Molecular mechanisms of how reduced levels of blood lipids can affect lipid rafts in immune-mediated disorders still remain to be addressed. However, atorvastatin reversed many of the signaling defects characteristic of T cells from patients with SLE (Jury et al. 2006). The possibility that atorvastatin targets lipid raft-associated signaling abnormalities in autoreactive $\mathrm{T}$ cells has been proposed as the rationale for its use in the therapy of autoimmune disease (Jury et al. 2006). This is further supported by a large observational study that demonstrated an association between persistence with statin therapy and reduced risk of developing RA (Chodick et al. 2010). More recently, Yvan-Charvet et al. reported that two key proteins involved in HDL cholesterol efflux such as ATP-binding cassette transporters ABCA1 and ABCG1 play a key role in hematopoietic stem and multipotential progenitor cell proliferation, thus further linking cholesterol efflux and lipid raft modulation to immune cell function (Yvan-Charvet et al. 2010a, b). Finally, a key role for apoA-I in controlling cholesterol-associated lymphocyte activation and proliferation in peripheral lymph nodes was observed in animal models (Wilhelm et al. 2009). The prevalence of classical CD14++/CD16- but not of intermediate CD14++/CD16+ monocytes in hypoalphalipoproteinemia should also be taken into account as could impact on the different polarization on APC cells (Sala et al. 2013). More recently, Wang et al. (2012) demonstrated that HDL and apoA-I-induced cholesterol depletion and consequent disruption of plasma membrane lipid rafts in APCs inhibit their capacity to stimulate T-cell activation. This mechanism is highly dependent on the reduction of MHC class II molecules present on the cell surface following ABCA1 activation and on cholesterol efflux supporting a role for HDL in controlling also lymphocyte-mediated responses. 


\section{Modulation of Spinghosine-1-Phosphate (S1P)/ S1P-Receptor Axis and Lymphocyte Function}

Among the lipids that concentrate in lipid rafts, sphingolipids represent a major class that is metabolized to generate ceramide and subsequently sphingosine that in turn could be phosphorylated by sphingosine kinase (SPHK) (expressed mainly in platelets and in other peripheral blood cells) to generate S1P (Scanu and Edelstein 2008). Free or albumin-bound S1P is more susceptible to degradation than S1P bound to HDL (Yatomi 2008), which suggests that the latter might have a role in determining the uptake, cellular degradation, and systemic function. S1P carried by HDL positively correlates with HDL cholesterol, apoA-I, and apoA-II levels; furthermore, S1P is enriched in small dense HDL3 (Scanu and Edelstein 2008). S1P signals through five known G protein-coupled receptors (S1P1-S1P5). Over the last few years, it become apparent that S1P and the key enzymes SPHKs play a central role in the pathogenesis of several inflammatory disorders, including rheumatoid arthritis, asthma, and atherosclerosis by modulating macrophage function through the control of apoptosis as well as cell trafficking (Weigert et al. 2009). Many of these effects might depend on the activation of different S1P receptors. The activation of the lysosphingolipid receptor-PI3K/Akt axis by sphingosine-1phosphate or other S1P mimetics is responsible for the induction by HDL of several genes involved in the immune response including the long pentraxin PTX3 or the transforming growth factor beta 2 (Norata et al. 2005, 2008). The S1P/S1P-receptor axis also plays a key role in lymphocyte function. The activation of S1P receptors and the consequent downstream signaling facilitate the egress of $\mathrm{T}$ cells from lymphoid organs (Mandala et al. 2002; Matloubian et al. 2004) and play a role in the lineage determination of peripheral T cells (Liu et al. 2010). S1P inhibits the differentiation of forkhead box $\mathrm{P} 3$ (FoxP3) ${ }^{+}$regulatory $\mathrm{T}$ cells $\left(\mathrm{T}_{\text {regs }}\right)$ while promoting the development of $\mathrm{T}$ helper type 1 (Th1) in a reciprocal manner (Liu et al. 2010). S1P receptor antagonizes TGF- $\beta$ receptor function through an inhibitory effect on SMAD-3 activities to control the dichotomy between these two T-cell lineages (Liu et al. 2010). In animal models, apoA-I reduces inflammation in LDL receptor $(-/-)$, apoA-I $(-/-)$ mice by augmenting the effectiveness of the lymph nodes' $\mathrm{T}_{\text {reg }}$ response, with an increase in $\mathrm{T}_{\text {reg }}$ and a decrease in the percentage of effector/effector memory T cells (Wilhelm et al. 2010). While marked changes of $\mathrm{T}_{\text {reg }}$ number/function (two- to threefold difference) have been associated with atheroprotective functions in animal models (Ait-Oufella et al. 2006; Mor et al. 2007), in humans the correlation between $T_{\text {reg }}$, immune, and cardiometabolic disorders is less clear. We found no association between circulating CD3 + CD4 $+\mathrm{CD} 25$ highCD127low $\mathrm{T}_{\text {reg }}$ levels and the extent or progression of human atherosclerotic disease at carotid and coronary sites (Ammirati et al. 2010). In a series of immune-mediated diseases such as rheumatoid arthritis, increased $\mathrm{T}_{\text {reg }}$ levels in synovial fluid of inflamed joints were observed (Mottonen et al. 2005; Bacchetta et al. 2007). Furthermore, Liu et al. observed relatively high $\mathrm{T}_{\text {reg-cell levels in }}$ patients with type 1 diabetes mellitus (Liu et al. 2006), and pathogenic T cells have been shown to have a paradoxical protective effect in murine autoimmune diabetes 
by boosting $T_{\text {regs }}$ (Grinberg-Bleyer et al. 2010). Of note, excessive IL-6 or TNF-alpha production was associated with increased $\mathrm{T}_{\text {reg }}$ levels (Fujimoto et al. 2011; Bilate and Lafaille 2010). This evidence suggests the possibility that $\mathrm{T}_{\text {reg }}$ numbers could increase during some stages of disease as an attempt to regulate effector-cell activity. Unexpectedly, in the general population, we observed an inverse relation between HDL-C and $\mathrm{T}_{\text {reg }}$ count (Ammirati et al. 2010); whether this finding suggests that HDL could influence the polarization of lymphocyte subsets or could be a bystander of the T-cell status remains to be addressed. Recent evidence on the role of S1P in immune surveillance and the discovery of regulatory mechanisms in S1P-mediated immune trafficking has prompted extensive investigation in the field of S1P-receptor pharmacology. Fingolimod (FTY720), an S1P-receptor modulator, prevents lymphocyte egress from lymph nodes and modulates lymphocyte differentiation (Chi 2011). Initially, fingolimod was used as immunosuppressant in solid organ transplantation (Tedesco-Silva et al. 2006), while MS has been the first disease in which fingolimod was tested. In MS the myelin sheaths around the axons of the brain and spinal cord are damaged by inflammatory processes, leading to demyelination. Current therapeutic approaches are focused on the suppression of the immune system and on the blockage of T-cell blood-brain barrier transmigration into the brain parenchyma. Treatment with fingolimod was effective in reducing the disability progression on a large cohort of patients with relapsing MS (Cohen et al. 2010; Kappos et al. 2010). Of note, MS patients during the phase of clinical remission showed increased levels of HDL and total cholesterol levels (Salemi et al. 2010), whereas in immune-mediated disorders with increased markers of systemic inflammation, HDL levels are often decreased. Fingolimod was assessed also in diseases with an immunological component, such as atherosclerosis (Nofer et al. 2007; Keul et al. 2007). In LDL receptor-deficient mice, fingolimod inhibits atherosclerosis by modulating lymphocyte and macrophage function. In this study plasma lipids remained unchanged during the course of fingolimod treatment, whereas fingolimod lowered blood lymphocyte count (Nofer et al. 2007). As S1P levels are increased in many inflammatory conditions, such as in asthma and autoimmunity, the exact mechanism by which S1PR agonists could modulate its function is debated (Rivera et al. 2008). Interestingly, fingolimod is highly active in inducing the internalization, ubiquitination, and subsequent degradation of S1PR1 (Graler and Goetzl 2004) which suggests that its inhibitory action on immune cell trafficking might be through receptor downregulation. It is therefore crucial to understand the effect of HDL contained $\mathrm{S} 1 \mathrm{P}$ on receptor expression and activity in immune disorders.

In spite of the presence of a number of experimental and clinical observations suggesting a relation between HDL and innate immunity, several questions remain to be addressed. Are the altered HDL-C levels a consequence of the atherogenic process, a cause of increased atherosclerosis observed in immune disorders, or independently related to the latter? How is HDL function altered in these diseases? Does raising HDL-C improve the outcome of immune disorders? As HDLs are a reservoir for several biologically active substances that may impact the immune system (Norata et al. 2012), how does the fine-tuning of lipid and protein exchange 
among lipoproteins affect HDL-related immune functions? Is there a specific HDL subfraction that is relevant? Addressing these aspects will be critical to understand the connection between HDL and the immune response.

\section{Inflammatory Diseases}

\subsection{Inflammatory Bowel Diseases}

The inflammatory bowel diseases (IBD) Crohn's disease (CD) and ulcerative colitis (UC) are chronic inflammatory diseases whose pathogenesis is not completely understood (Williams et al. 2012) but seems to be linked to autoimmune phenomena in a genetically prone background, following an abnormal immune response to colonic bacteria, and facilitated by a Western-type diet. IBD are associated with marked atherosclerosis and increased cardiovascular risk. Infection and chronic inflammation impair and alter lipoprotein metabolism and cause a variety of changes in plasma concentrations of lipids and lipoproteins (Borba et al. 2006; de Carvalho et al. 2008). An increase in inflammatory cytokines may result in a decrease in LPL enzyme activity, leading to a characteristic lipoprotein profile with decreased HDL-C levels as seen in patients with IBD that have high circulatory levels of inflammatory cytokines (Williams et al. 2012; Sappati Biyyani et al. 2010).

$\mathrm{CD}$ is a chronic inflammatory bowel disease that can affect any region of the gastrointestinal tract (Grand et al. 1995) with increased chronic inflammatory cell infiltrates in the mucosal lesions. The excessive local production of soluble mediators from activated monocytes and polymorphonuclear leukocytes has been implicated in mediating the tissue injury (Weiss 1989). Important among these mediators are oxygen free radicals. The chronic gut inflammation promotes an imbalance between oxidant and antioxidant mechanisms at the tissue level (Buffinton and Doe 1995) and may even compromise circulating antioxidant concentrations. A chronic inflammatory state is a risk factor for accelerated atherogenesis (van Leuven et al. 2007). A recent exploratory analysis demonstrated that $\mathrm{CD}$ is associated with an acceleration of the atherosclerotic process, as illustrated by an increased carotid intima-media thickness (IMT) in CD patients compared to healthy controls. In addition, CD patients were characterized during an inflammatory exacerbation by profoundly decreased levels of HDL combined with biochemical changes of the HDL particles, such as association with serum amyloid A, suggesting that early detection of atherosclerosis and subsequent cardiovascular prevention in patients with CD might be warranted (Romanato et al. 2009).

\subsection{Vasculitis}

Behçet's disease (BD) is a systemic vasculitis, most common in the Mediterranean area and in Asia, which can involve nearly every organ system and results from the interplay between infectious agent exposure and genetic factors. High production of 
cytokines, T and B lymphocyte activation, autoantibody production, and hypercoagulable/prothrombotic state are all characteristics of BD. Evidence for accelerated atherosclerosis in $\mathrm{BD}$ has been observed, but the relationship between cardiovascular risk factors and accelerated atherosclerosis in patients with BD is still controversial (Messedi et al. 2011). A study published by Messedi and colleagues demonstrated that in BD patients, HDL concentration and their subfraction levels are decreased. The same study reported that the percentage of HDL2 subpopulation was also decreased and HDL3 subfraction was significantly higher. The LDL-C/ HDL-C ratio and CRP level were increased, and HDL and its subfractions were correlated with CRP and TG levels, suggesting that all these parameters may be considered as important predictors of cardiovascular events in BD patients (Messedi et al. 2011). This study confirms what seen in some previous studies in which, compared to control subjects, $\mathrm{BD}$ patients were characterized by reduced levels of HDL (Cimen et al. 2012; Musabak et al. 2005; Orem et al. 2002).

Kawasaki disease (KD) is an acute vasculitis that predominantly occurs in infancy and early childhood. It is commonly thought that KD results from the exposure of a genetically predisposed individual to an as-yet unidentified, possibly infectious environmental trigger. Coronary artery aneurysms or ectasia develops in approximately 15-25\% of affected children (Dhillon et al. 1996; Newburger et al. 1991; Cheung et al. 2004). There is increasing evidence to suggest that children with a history of KD might be predisposed to premature atherosclerosis and a significant association between carotid IMT and systemic arterial stiffness in children after KD has been demonstrated (Cheung et al. 2007). This syndrome is associated with significant abnormalities in lipid profile. In one of the first studies on this subject, it was shown that in the earliest days of illness, mean plasma concentrations of total cholesterol and HDL cholesterol are profoundly depressed, whereas mean triglyceride concentration is very high. Total cholesterol values rapidly return to normal and remain stable for more than 3 months after the onset of illness. HDL concentration recovered more slowly after illness onset, and mean HDL was significantly lower than expected more than 3 years after illness onset (Newburger et al. 1991). The persistence of low HDL for many years suggests a more lasting effect of KD on endothelial function, perhaps attributable to diminished activity of lipoprotein lipase. This enzyme resides on the capillary walls of most tissues and functions at the luminal surface of the vascular endothelium (Eckel 1989). This observation is confirmed, at least in part, in later studies on the lipid derangement in KD (Cheung et al. 2004; Chiang et al. 1997; Cabana et al. 1997). The results showed that during the acute phase, the concentrations of plasma HDL-C, apoA-I, and apoA-II were significantly reduced and the reduction of HDL was mainly related to the lowering of esterified and unesterified cholesterol in HDL2 (Chiang et al. 1997). In parallel, another study demonstrated that the lipid changes involved not only HDL-C concentration but also HDL composition. The authors showed that children with KD have extremely low serum HDL-C and apoA-I levels at the time of the acute illness and that serum amyloid A (SAA) is present in the acute stage and is associated mainly with HDL particles of HDL3 density (Cabana et al. 1997). Moreover, a more recent study demonstrated a 
significant induction of MCP-1, CCR2, and iNOS expression in THP-1 macrophages in vitro by the serum of children with a history of KD, showing that this induction correlated positively with serum high-sensitivity C-reactive protein (hs-CRP) and LDL and negatively with HDL-C levels (Cheung et al. 2005).

\subsection{Psoriasis}

Psoriasis is a chronic inflammatory skin disease associated with arthritis in up to $40 \%$ of cases. Genetic and environmental factors contribute to the activation of lymphocytes, particularly Th1 and Th17, monocytes/macrophages, and dendritic cells and to the high cytokine content typical of psoriatic lesions. Psoriasis is associated with increased incidence of stroke and CVD (Yu et al. 2012) and with increased mean carotid IMT (Troitzsch et al. 2012). The mechanism behind such associations is still unknown. It is possible that the chronic inflammatory environment and high cytokine production typical of psoriasis induce abnormal HDL particle composition (El Harchaoui et al. 2009; McGillicuddy et al. 2009). A similar chronic inflammatory environment is observed in psoriasis (Davidovici et al. 2010) and contributes to the increased incidence of aortic inflammation, stroke, and myocardial infarction seen in this patient population (Mehta et al. 2011; Gelfand et al. 2006).

Lipoprotein profiling by NMR spectroscopy showed a reduction of HDL in psoriatic patients compared to controls, with an atherogenic profile with respect to HDL particles. In particular, high HDL-C concentration and large HDL size were associated with less aortic inflammation, while small HDL particles were more prevalent in cases with strong inflammation. Such association persisted following adjustment for $\mathrm{CV}$ risk factors, suggesting that HDL particle characteristics may play an important role in psoriatic vascular inflammation and CVD (Yu et al. 2012). HDL reduction in psoriatic patients has also been described to be associated to a reduction of serum cholesterol efflux capacity compared to control subjects (Mehta et al. 2012). In this study, psoriasis activity was inversely associated with HDL efflux capacity in a way depending on HDL particle size. Holzer and colleagues demonstrated that the protein composition of HDL is markedly altered in patients with psoriasis. ApoA-I and apoM levels are decreased, whereas the levels of several acute-phase proteins such as SAA, prothrombin, $\alpha$-2-HS-glycoprotein, and $\alpha$-1-acid glycoprotein 1 are increased (Holzer et al. 2012). Additionally, also the lipid composition of HDL from patients with psoriasis was altered, with a decrease in total cholesterol, cholesterol ester, free cholesterol, phosphatidylcholine, and sphingomyelin. These investigators confirmed that HDL from patients with psoriasis was less efficient in promoting cholesterol efflux from macrophages and that this defect in HDL function correlated with the severity of psoriasis. Surprisingly, the antioxidant properties of HDL were similar in control and psoriatic HDL and PON activity was not altered. However, Lp-PLA2 activity was increased and correlated with disease activity (Holzer et al. 2012). This observation does not completely agree with a report showing that the PON1 $55 \mathrm{M}$ allele is a risk factor for psoriasis. 
Carriers of this allele have high levels of apoB and $\mathrm{Lp}(\mathrm{a})$ and a high apoB/apoA-I ratio, indicating that oxidative stress, impairment of the antioxidant system, and abnormal lipid metabolism may play a role in the pathogenesis and progression of psoriasis and its related complications (Asefi et al. 2012). Moreover, the paper by Holzer and coworkers demonstrates that a relatively mild chronic inflammatory state can similarly result in dysfunctional HDL, leading to decreased cholesterol efflux from macrophages (Holzer et al. 2012).

\section{Autoimmune Diseases: The Role of Autoantibodies}

\subsection{Systemic Lupus Erythematosus (SLE)}

SLE is a systemic autoimmune disease of multifactorial origin, in which genetic and environmental factors induce innate and acquired immunity derangement, with type I interferon (INF) production, T- and B-cell dysregulation, autoantibody production, and finally multiple organ damage. SLE is associated with accelerated atherosclerosis and markedly increased cardiovascular risk (CVR) (Shoenfeld et al. 2005). As in other autoimmune disorders, CVR cannot be fully explained by traditional risk factors, and various specific immune and inflammatory mechanisms have been demonstrated or proposed. The modifications of HDL level and function occurring in SLE have been indicated as possible factors contributing to cardiovascular damage.

Decreased circulating HDL-C levels have been often reported, although not unanimously, in SLE patients with active disease (de Carvalho et al. 2008; Hahn et al. 2008; Kiss et al. 2007), but the actual relevance of this finding with respect to CVR has not been clarified so far. The most important pro-atherogenic modifications seem to be those relative to composition and function of HDL. HDLs in SLE have impaired anti-inflammatory and antioxidant properties. In SLE, the so-called proinflammatory HDL (piHDL) can be detected in as many as $45 \%$ of patients, correlating with increased oxidized LDL formation, carotid plaque, and carotid intima-media thickness (cIMT) (McMahon et al. 2011). piHDL are characterized by decreased content in the protective proteins paraoxonase (PON1) and apoA-I and by markedly increased levels of the pro-oxidant SAA (Hahn et al. 2008). These HDLs can be defined as proinflammatory because they actually enhance the oxidation of LDL and therefore monocyte attraction/activation, antioxLDL antibody production, and immune complex formation (Hahn et al. 2008; Teixeira et al. 2012; Carbone et al. 2013; Vuilleumier et al. 2014). It has been shown that the reduced activity of PON1 in some cases may be due also to the action of antiapoA-I and anti-HDL antibodies (O'Neill et al. 2010; Batuca et al. 2007). Anti-apoAI antibodies, first described in SLE patients but detected also in patients with acute coronary syndrome, have shown independent association and predictive value with respect to cardiovascular events in various patient populations (Carbone et al. 2013). Proposed mechanisms for such association include the ability of anti-apoA-I antibodies to induce HDL dysfunction, scavenger receptor B1 (SR-BI) function 
impairment in endothelial cells, neutrophil infiltration and matrix-metalloproteinase 9 production in plaques, activation of NFkB via TLR2/CD14 complex interaction, and cytokine release (Carbone et al. 2013). Interestingly, anti-apoA-I and anti-HDL antibodies have been shown to correlate also with disease activity in SLE patients (O'Neill et al. 2010).

In addition, HDL dysfunction in SLE involves their capacity to promote cell cholesterol efflux (Ronda et al. 2014). In particular, in SLE patients HDL cholesterol efflux capacity (CEC) is reduced with respect to the ABCG1 and ABCA1 transporter pathways, while the SR-BI-mediated CEC is unchanged. In addition the correlation between SR-BI-mediated CEC and HDL-C levels was stronger in SLE plasmas as compared to control plasma. This pattern is consistent with a possible reduction/dysfunction of the small HDL populations (Favari et al. 2009) and a shift to larger HDL, typical acceptors of cholesterol effluxed by SR-BI. Indeed, HDLs of SLE patients were found increased in size (Hua et al. 2009; Juárez-Rojas et al. 2008). The impaired ABCA1- and ABCG1-mediated CEC in SLE patients may have a great impact because cholesterol efflux not only opposes lipid deposition in vessels but is also crucial for the modulation of macrophage, endothelial, and T-cell inflammatory functions (Prosser et al. 2012; Yvan-Charvet et al. 2010a, b).

\subsection{Rheumatoid Arthritis (RA)}

RA is a systemic autoimmune disease characterized by lymphocyte activation, autoantibody production, high serum and tissue cytokine levels, and strong inflammation of synovia and vessels; similarly to SLE, it is associated with high CV risk (Shoenfeld et al. 2005). Circulating levels of HDL-C are often reduced, especially in active disease, and generally return to normal values during drug-induced remission; however, as such modifications are mirrored by those relative to LDL cholesterol and total cholesterol, the actual clinical significance of HDL-C variation is not clear. Complex and specific mechanisms underlie lipid metabolism derangement in RA, in which cardiovascular risk inversely correlates with circulating LDL-C levels (the so-called RA lipid paradox) (Myasoedova et al. 2011). As in SLE, the clinical relevance of HDL-C lowering (when present) in RA patients has yet to be clarified.

Composition and functional characteristics of HDL are altered in RA. piHDL levels are increased in RA patients as compared to healthy controls (Hahn et al. 2008) and correlate positively with disease activity (Charles-Schoeman et al. 2009). Profound modifications of HDL composition in patients with active RA have been described, particularly with respect to protein content. These changes include increased amount of serum amyloid A (SAA), apoJ, fibrinogen, and haptoglobin and reduced PON1 (Charles-Schoeman et al. 2009; Watanabe et al. 2012). As in SLE, anti-apoA-I autoantibodies are detectable in the serum of RA patients. In particular, in this population anti-apoA-I IgG levels have been shown to predict acute cardiovascular events and improve the prognostic power of the Framingham Risk Score (Carbone et al. 2013). 
Finally, functional impairment of HDL as cholesterol acceptors for cell cholesterol efflux has been reported in RA (Ronda et al. 2014; Charles-Schoeman et al. 2012), independent of serum HDL-C levels and with a pattern of modifications differing from that found in SLE patients with respect to single cholesterol transporters (Ronda et al. 2014). In particular, ABCG1-mediated CEC is impaired in RA patients independently of HDL-C levels but inversely correlating with disease activity (Ronda et al. 2014). On the one hand, such correlation may reflect the impact of inflammation and autoimmunity on HDL function, but on the other hand, it may indicate the adverse effect of reduced ABCG1-mediated CEC on vessel inflammation and immune reaction promotion. In fact, by promoting cholesterol and 7-ketocholesterol release, ABCG1 promotes anti-inflammatory phenotypes of macrophages and endothelial cells (Terasaka et al. 2007; Hassan et al. 2006; O'Connell et al. 2004).

Modifications of HDL occurring in SLE and RA compromise cholesterol effluxpromoting, anti-inflammatory, and antioxidant properties of HDL and thereby may have an important role in the progression of both atherosclerosis and autoimmune as well as inflammatory phenomena typical for these diseases.

\section{Impact of Anti-inflammatory Treatments}

HDL exerts potent and multifactorial anti-inflammatory effects, which makes it an attractive target for pharmacological intervention. As extensively discussed in this chapter, several molecular principles exploited by HDL particles to interfere with innate or acquired immunity might be well utilized for designing new drugs effectively combating atherosclerosis and/or autoimmune diseases. By contrast, little efforts have been devoted to assess the influence of medication traditionally used in acute or chronic inflammatory diseases on HDL-C levels and HDL function. Most information regarding the interrelationship between HDL and antiinflammatory therapy stems from interventional studies designed to examine the impact of drugs on the primary disease rather than on lipid metabolism. Despite this limited approach, currently available data strongly suggest that anti-inflammatory medication may exert positive adjuvant effects both on HDL quantity and its functionality.

It is well known that HDL is a negative acute-phase reactant and that HDL-C levels decline - sometimes dramatically — at the onset of acute inflammation and infection. For instance, sepsis, extensive surgery, or viral infections are commonly associated with low HDL-C levels that are significantly and rapidly increased following spontaneous or treatment-related reductions in disease activity (Marik 2006; Akgun et al. 1998; Marchesi et al. 2005). In addition, several chronic autoimmune disorders including SLE, RA, Kawasaki disease, and Behçet's disease as well as periodontal disease are accompanied by decreased HDL levels in plasma (Haas and Mooradian 2011). Hence, the administration of nonsteroidal antiinflammatory drugs (NSAIDs), which represent the most often prescribed class of anti-inflammatory drugs, might be expected to produce HDL-C elevations by the 
simple reversal of the acute-phase reaction. However, the effect of NSAIDs on the quantity and quality of HDL remains controversial. In animal studies rising effects of aspirin on ABCA1 expression and cholesterol efflux as well as on lecithincholesterol acyltransferase (LCAT) activity and plasma HDL-C levels were occasionally observed (Sethi et al. 2011; Jafarnejad et al. 2008; Viñals et al. 2005). However, these effects apparently did not translate into increased HDL generation, as similar plasma HDL-C levels were noted in a small prospective study in aspirinand placebo-treated groups (Eritsland et al. 1989). In one study, the administration of ibuprofen was found to slightly elevate HDL-C levels both in smokers and nonsmokers, whereas in another study treatment with naproxen failed to show any effect (Zapolska-Downar et al. 2000; Young et al. 1995). The influence of selective cyclooxygenase-2 inhibitors such as celecoxib or rofecoxib on HDL-C plasma levels has not been reported to date. In a more recent investigation, atreleuton (VIA-2291) — the first clinically tested 5-lipooxygenase inhibitor-was found to decrease leukotriene B4 production and CRP levels in blood and to concomitantly reduce coronary plaque burden, but these favorable effects were observed in the absence of any changes in plasma lipid profile including HDL-C (Tardif et al. 2010).

In a major contrast to nonsteroidal antiphlogistics, corticosteroids were repeatedly reported to increase plasma HDL-C levels in patients with chronic autoimmune diseases including RA, psoriatic arthritis, and SLE as well as in a non-autoimmune chronic inflammation (sarcoidosis) (Ettinger et al. 1987; Salazar et al. 2002; Boers et al. 2003; Sarkissian et al. 2007; Peters et al. 2007; Georgiadis et al. 2008; García-Gómez et al. 2008). Furthermore, the addition of corticosteroids to disease-modifying antirheumatic drugs (DMARDs, such as methotrexate or sulfasalazine), which on their own increase HDL-C in plasma, significantly potentiated their effects on HDL-C levels (Boers et al. 2003). In one study, corticosteroids were also found to favorably affect HDL subfractions by preferentially increasing the amount of HDL2-C over HDL3-C (García-Gómez et al. 2008). The beneficial effects exerted by corticosteroids on HDL quantity may appear at the first glimpse counterintuitive, since protracted therapy with these compounds is known to enhance insulin resistance and to produce a prediabetic state, which is almost obligatorily accompanied by low HDL-C. Actually, endogenous hypercortisolism (Cushing disease) has been related both to decreased HDL-C levels and to increased cardiovascular risk in several studies (Faggiano et al. 2003). However, the relationship between steroid use and cardiovascular risk is complicated by the fact that these drugs tend to be used more often in patients with severe or intractable chronic disease; in such patients, the anti-inflammatory HDL-C elevating effect of corticosteroids may outweigh the HDL-C decreasing effect related to aggravation of insulin resistance. The mechanisms underlying modulatory effects of corticosteroids on HDL metabolism remain obscure. These compounds were found to increase the activity of lipoprotein lipase (LPL) and to decrease the activity of hepatic triglyceride lipase, which are both critically involved in the generation of HDL precursors and in HDL particle remodeling (Ewart et al. 1997; Dolinsky et al. 2004). In addition, corticosteroids may stimulate the production of nascent 
HDL as they enhance apoA-I gene expression in hepatocytes (Hargrove et al. 1999). Finally, corticosteroids were found to inhibit the activity of cholesteryl ester transfer protein (CETP), which may well explain their modulatory effect on the HDL subfraction composition (Georgiadis et al. 2006).

Studies involving biological pharmaceuticals, which selectively interfere with proinflammatory signaling pathways, add further evidence underscoring the beneficial effects of anti-inflammatory therapies on HDL quantity in plasma. The greatest amount of research into the effects of biologicals on lipids has been performed with TNF-alpha antagonists, in particular, with infliximab. In general, these studies demonstrated a consistent action of this drug in patients with RA, ankylosing spondylitis, and inflammatory bowel disease characterized by increases in total cholesterol mostly due to the elevation of HDL-C (Choy and Sattar 2009; Pollono et al. 2010; Mathieu et al. 2010; Koutroubakis et al. 2009; ParmentierDecrucq et al. 2009). Similar effects on HDL-C were observed in studies utilizing two other TNF-alpha antagonists, adalimumab and, most recently, golimumab, whereas the application of etanercept - a TNF-alpha receptor antagonist-produced less consistent results (Pollono et al. 2010; Stagakis et al. 2012; NavarroMillán et al. 2013; Lestre et al. 2011; Kirkham et al. 2014). Positive effects on plasma lipid profile encompassing the elevation of HDL-C levels were also observed in patients with RA undergoing IL-6 receptor blockade with tocilizumab or CD20 signaling blockade with rituximab (Pollono et al. 2010; Kawashiri et al. 2011; Kerekes et al. 2009). In a major contrast, canakinumab-a compound neutralizing IL-1beta-failed to change plasma lipid profile in a large randomized study involving 556 men and women at high cardiovascular risk, albeit the treatment led to significant reductions in acute-phase proteins such as CRP and fibrinogen (Ridker et al. 2012). The molecular mechanisms underlying the beneficial effects of biological therapies on HDL-C levels are poorly understood. While it cannot be entirely excluded that HDL-C increases are at least partly related to the retardation of acute-phase reaction brought about by the inhibition of selected proinflammatory signaling pathways, it seems more likely that treatment with TNF-alpha or IL-6 antagonists leads to derepression of the APOA1 gene, the activity of which is known to be downregulated in hepatocytes exposed to proinflammatory cytokines (Haas and Mooradian 2011).

In addition to the reduction of HDL quantity, acute-phase reaction was demonstrated to profoundly affect HDL composition. HDL particles isolated from subjects suffering from acute or chronic inflammatory diseases were found to lose proteins and enzymes with established or presumed antiatherogenic function such as apoA-I, LCAT, or PON1 and to concomitantly acquire proinflammatory or pro-oxidative factors such as SAA, ceruloplasmin, Lp-PLA2, or MPO. Such inflammatory HDL particles are severely impeded in their ability to exert several antiatherogenic functions including initiation of reversed cholesterol transport, inhibition of pro-oxidative processes, inhibition of leukocyte migration and recruitment into arterial wall, or inhibition of thrombocyte activation. The picture emerging from few recent studies suggests that anti-inflammatory medications may not only elevate HDL quantity in plasma but also help to restore its proper 
composition and thereby the antiatherogenic functionality. For instance, treatment of RA patients with adalimumab, etanercept, tocilizumab, or rituximab decreased and increased the content of SAA and apoA-I in HDL particles, respectively (Raterman et al. 2013; McInnes et al. 2014; Jamnitski et al. 2013). In addition, prolonged therapy with methotrexate was found to improve the capacity of HDL to inhibit both LDL oxidation and leukocyte migration in patients with RA (CharlesSchoeman et al. 2009). Increased levels of HDL-associated PON1 and improved anti-oxidative capacity were seen in patients with psoriasis treated with etanercept (Bacchetti et al. 2013).

\section{Conclusions}

HDL particles have been shown to play a protective and an anti-inflammatory role in autoimmune and inflammatory disorders. Their pathophysiological relevance directly implies the regulation of both immune and vascular cell functions that influence the common inflammatory processes underlying disease progression and the associated CV risk. Numerous studies have demonstrated that inflammatory disorders increase the risk of CVD and that this increase cannot be totally accounted for by traditional risk factors. Alterations in the quantity, composition, and function of HDL may contribute to the promotion of atherosclerosis process. In this prospective the assessment of HDL function, evaluated as the capacity to promote cell cholesterol efflux, may offer a better prediction of CVD than classical HDL-C levels. In addition, HDL function impairment, which involves their anti-inflammatory and antioxidant properties as well as their ability to interact with cellular cholesterol transporters, may have an important role in accelerating atherosclerosis but also autoimmune and inflammatory mechanisms typical for these diseases. Therefore, the improvement of HDL function (instead of HDL-C levels) represents an interesting therapeutic strategy to reduce inflammation and associated $\mathrm{CV}$ risk in several immune diseases, such as systemic lupus erythematosus and rheumatoid arthritis. We believe that selective treatments improving HDL function or reducing the adverse modifications of HDL structure might be of pathophysiological relevance. Both basic and clinical studies are needed to validate this promising therapeutic issue in a near future.

Open Access This chapter is distributed under the terms of the Creative Commons Attribution Noncommercial License, which permits any noncommercial use, distribution, and reproduction in any medium, provided the original author(s) and source are credited.

\section{References}

Ait-Oufella H, Salomon BL, Potteaux S, Robertson AK, Gourdy P, Zoll J, Merval R, Esposito B, Cohen JL, Fisson S, Flavell RA, Hansson GK, Klatzmann D, Tedgui A, Mallat Z (2006) Natural regulatory $\mathrm{T}$ cells control the development of atherosclerosis in mice. Nat Med 12:178-180 
Akgun S, Ertel NH, Mosenthal A, Oser W (1998) Postsurgical reduction of serum lipoproteins: interleukin-6 and the acute-phase response. J Lab Clin Med 131:103-108

Ammirati E, Cianflone D, Banfi M, Vecchio V, Palini A, De Metrio M, Marenzi G, Panciroli C, Tumminello G, Anzuini A, Palloshi A, Grigore L, Garlaschelli K, Tramontana S, Tavano D, Airoldi F, Manfredi AA, Catapano AL, Norata GD (2010) Circulating CD4+CD25hiCD127lo regulatory t-cell levels do not reflect the extent or severity of carotid and coronary atherosclerosis. Arterioscler Thromb Vasc Biol 30:1832-1841

Ammirati E, Cianflone D, Vecchio V, Banfi M, Vermi AC, De Metrio M, Grigore L, Pellegatta F, Pirillo A, Garlaschelli K, Manfredi AA, Catapano AL, Maseri A, Palini AG, Norata GD (2012a) Effector memory $\mathrm{T}$ cells are associated with atherosclerosis in humans and animal models. J Am Heart Assoc 1:27-41

Ammirati E, Monaco C, Norata GD (2012b) Antigen-dependent and antigen-independent pathways modulate CD4+CD28null T-cells during atherosclerosis. Circ Res 111:e48-e49

Asefi M, Vaisi-Raygani A, Bahrehmand F, Kiani A, Rahimi Z, Nomani H, Ebrahimi A, Tavilani H, Pourmotabbed T (2012) Paraoxonase 1 (PON1) 55 polymorphism, lipid profiles and psoriasis. Br J Dermatol 167:1279-1286

Babin PJ, Thisse C, Durliat M, Andre M, Akimenko MA, Thisse B (1997) Both apolipoprotein E and A-I genes are present in a nonmammalian vertebrate and are highly expressed during embryonic development. Proc Natl Acad Sci USA 94:8622-8627

Bacchetta R, Gambineri E, Roncarolo MG (2007) Role of regulatory T cells and FOXP3 in human diseases. J Allergy Clin Immunol 120:227-235

Bacchetti T, Campanati A, Ferretti G, Simonetti O, Liberati G, Offidani AM (2013) Oxidative stress and psoriasis: the effect of antitumour necrosis factor- $\alpha$ inhibitor treatment. $\mathrm{Br} \mathrm{J}$ Dermatol 168:984-989

Baniyash M (2004) TCR zeta-chain downregulation: curtailing an excessive inflammatory immune response. Nat Rev Immunol 4:675-687

Batuca JR, Ames PR, Isenberg DA, Alves JD (2007) Antibodies toward high-density lipoprotein components inhibit paraoxonase activity in patients with systemic lupus erythematosus. Ann N Y Acad Sci 1108:137-146

Beck WH, Adams CP, Biglang-Awa IM, Patel AB, Vincent H, Haas-Stapleton EJ, Weers PM (2013) Apolipoprotein A-I binding to anionic vesicles and lipopolysaccharides: role for lysine residues in antimicrobial properties. Biochim Biophys Acta 1828:1503-1510

Bilate AM, Lafaille JJ (2010) Can TNF-alpha boost regulatory T cells? J Clin Invest 120:4190-4192

Boers M, Nurmohamed MT, Doelman CJ, Lard LR, Verhoeven AC, Voskuyl AE, Huizinga TW, van de Stadt RJ, Dijkmans BA, van der Linden S (2003) Influence of glucocorticoids and disease activity on total and high density lipoprotein cholesterol in patients with rheumatoid arthritis. Ann Rheum Dis 62:842-845

Borba EF, Carvalho JF, Bonfa E (2006) Mechanisms of dyslipoproteinemias in systemic lupus erythematosus. Clin Dev Immunol 13:203-208

Buffinton GD, Doe WF (1995) Depleted mucosal antioxidant defences in inflammatory bowel disease. Free Radic Biol Med 19:911-918

Cabana VG, Gidding SS, Getz GS, Chapman J, Shulman ST (1997) Serum amyloid A and high density lipoprotein participate in the acute phase response of Kawasaki disease. Pediatr Res 42:651-655

Carbone F, Nencioni A, Mach F, Vuilleumier N, Montecucco F (2013) Evidence on the pathogenic role of auto-antibodies in acute cardiovascular diseases. Thromb Haemost 109:854-868

Castelli WP, Garrison RJ, Wilson PW, Abbott RD, Kalousdian S, Kannel WB (1986) Incidence of coronary heart disease and lipoprotein cholesterol levels. The Framingham study. JAMA 256:2835-2838

Charles-Schoeman C, Watanabe J, Lee YY, Furst DE, Amjadi S, Elashoff D, Park G, McMahon M, Paulus HE, Fogelman AM, Reddy ST (2009) Abnormal function of high- 
density lipoprotein is associated with poor disease control and an altered protein cargo in rheumatoid arthritis. Arthritis Rheum 60:2870-2879

Charles-Schoeman C, Lee YY, Grijalva V, Amjadi S, FitzGerald J, Ranganath VK, Taylor M, McMahon M, Paulus HE, Reddy ST (2012) Cholesterol efflux by high density lipoproteins is impaired in patients with active rheumatoid arthritis. Ann Rheum Dis 71:1157-1162

Cheng AM, Handa P, Tateya S, Schwartz J, Tang C, Mitra P, Oram JF, Chait A, Kim F (2012) Apolipoprotein A-I attenuates palmitate-mediated NF- $\mathrm{kB}$ activation by reducing Toll-like receptor-4 recruitment into lipid rafts. PLoS ONE 7:e33917

Cheung YF, Yung TC, Tam SC, Ho MH, Chau AK (2004) Novel and traditional cardiovascular risk factors in children after Kawasaki disease: implications for premature atherosclerosis. $\mathrm{J}$ Am Coll Cardiol 43:120-124

Cheung YF, O K, Tam SC, Siow YL (2005) Induction of MCP1, CCR2, and iNOS expression in THP-1 macrophages by serum of children late after Kawasaki disease. Pediatr Res 58:1306-1310

Cheung YF, Wong SJ, Ho MH (2007) Relationship between carotid intima-media thickness and arterial stiffness in children after Kawasaki disease. Arch Dis Child 92:43-47

Chi H (2011) Sphingosine-1-phosphate and immune regulation: trafficking and beyond. Trends Pharmacol Sci 32:16-24

Chiang AN, Hwang B, Shaw GC, Lee BC, Lu JH, Meng CC, Chou P (1997) Changes in plasma levels of lipids and lipoprotein composition in patients with Kawasaki disease. Clin Chim Acta 260:15-26

Chodick G, Amital H, Shalem Y, Kokia E, Heymann AD, Porath A, Shalev V (2010) Persistence with statins and onset of rheumatoid arthritis: a population-based cohort study. PLoS Med 7: e1000336

Choy E, Sattar N (2009) Interpreting lipid levels in the context of high-grade inflammatory states with a focus on rheumatoid arthritis: a challenge to conventional cardiovascular risk actions. Ann Rheum Dis 68:460-469

Cimen F, Yildirmak ST, Ergen A, Cakmak M, Dogan S, Yenice N, Sezgin F (2012) Serum lipid, lipoprotein and oxidatively modified low density lipoprotein levels in active or inactive patients with Behcet's disease. Indian J Dermatol 57:97-101

Cohen JA, Barkhof F, Comi G, Hartung HP, Khatri BO, Montalban X, Pelletier J, Capra R, Gallo P, Izquierdo G, Tiel-Wilck K, de Vera A, Jin J, Stites T, Wu S, Aradhye S, Kappos L, TRANSFORMS Study Group (2010) Oral fingolimod or intramuscular interferon for relapsing multiple sclerosis. N Engl J Med 362:402-415

Davidovici BB, Sattar N, Prinz J, Puig L, Emery P, Barker JN, van de Kerkhof P, Stahle M, Nestle FO, Girolomoni G, Krueger JG (2010) Psoriasis and systemic inflammatory diseases: potential mechanistic links between skin disease and co-morbid conditions. J Invest Dermatol 130:1785-1796

Davidson MH (2012) HDL and CETP inhibition: will this DEFINE the future? Curr Treat Options Cardiovasc Med 14:384-390

de Carvalho JF, Bonfá E, Borba EF (2008) Systemic lupus erythematosus and "lupus dyslipoproteinemia". Autoimmun Rev 7:246-250

De Nardo D, Labzin LI, Kono H, Seki R, Schmidt SV, Beyer M, Xu D, Zimmer S, Lahrmann C, Schildberg FA, Vogelhuber J, Kraut M, Ulas T, Kerksiek A, Krebs W, Bode N, Grebe A, Fitzgerald ML, Hernandez NJ, Williams BR, Knolle P, Kneilling M, Röcken M, Lütjohann D, Wright SD, Schultze JL, Latz E (2014) High-density lipoprotein mediates anti-inflammatory reprogramming of macrophages via the transcriptional regulator ATF3. Nat Immunol 15:152-160

Dhillon R, Clarkson P, Donald AE, Powe AJ, Nash M, Novelli V, Dillon MJ, Deanfield JE (1996) Endothelial dysfunction late after Kawasaki disease. Circulation 94:2103-2106

Di Angelantonio E, Sarwar N, Perry P, Kaptoge S, Ray KK, Thompson A, Wood AM, Lewington S, Sattar N, Packard CJ, Collins R, Thompson SG, Danesh J, Emerging Risk 
Factors Collaboration (2009) Major lipids, apolipoproteins, and risk of vascular disease. JAMA 302:1993-2000

Dolinsky VW, Douglas DN, Lehner R, Vance DE (2004) Regulation of the enzymes of hepatic microsomal triacylglycerol lipolysis and re-esterification by the glucocorticoid dexamethasone. Biochem J 378:967-974

Eckel RH (1989) Lipoprotein lipase. A multifunctional enzyme relevant to common metabolic diseases. N Engl J Med 320:1060-1068

Ehrenstein MR, Jury EC, Mauri C (2005) Statins for atherosclerosis-as good as it gets? N Engl J Med 352:73-75

El Harchaoui K, Arsenault BJ, Franssen R, Despres JP, Hovingh GK, Stroes ES, Otvos JD, Wareham NJ, Kastelein JJ, Khaw KT, Boekholdt SM (2009) High-density lipoprotein particle size and concentration and coronary risk. Ann Intern Med 150:84-93

Eritsland J, Arnesen H, Smith P, Seljeflot I, Dahl K (1989) Effects of highly concentrated omega-3 polyunsaturated fatty acids and acetylsalicylic acid, alone and combined, on bleeding time and serum lipid profile. J Oslo City Hosp 39:97-101

Ettinger WH, Klinefelter HF, Kwiterovitch PO (1987) Effect of short-term, low-dose corticosteroids on plasma lipoprotein lipids. Atherosclerosis 63:167-172

Ewart HS, Carroll R, Severson DL (1997) Lipoprotein lipase activity in rat cardiomyocytes is stimulated by insulin and dexamethasone. Biochem J 327:439-442

Expert Panel on Detection Evaluation, and Treatment of High Blood Cholesterol in Adults (2001) Executive summary of the third report of the national cholesterol education program (NCEP) expert panel on detection, evaluation, and treatment of high blood cholesterol in adults (Adult Treatment Panel III). JAMA 285:2486-2497

Faggiano A, Pivonello R, Spiezia S, De Martino MC, Filippella M, Di Somma C, Lombardi G, Colao A (2003) Cardiovascular risk factors and common carotid artery calibre and stiffness in patients with Cushing's disease during active disease and 1 year after disease remission. J Clin Endocrinol Metab 88:2527-2533

Favari E, Calabresi L, Adorni MP, Jessup W, Simonelli S, Franceschini G, Bernini F (2009) Small discoidal pre-beta1 HDL particles are efficient acceptors of cell cholesterol via ABCA1 and ABCG1. Biochemistry 48:11067-11074

Flores-Borja F, Kabouridis PS, Jury EC, Isenberg DA, Mageed RA (2005) Decreased Lyn expression and translocation to lipid raft signaling domains in B lymphocytes from patients with systemic lupus erythematosus. Arthritis Rheum 52:3955-3965

Fujimoto M, Nakano M, Terabe F, Kawahata H, Ohkawara T, Han Y, Ripley B, Serada S, Nishikawa T, Kimura A, Nomura S, Kishimoto T, Naka T (2011) The influence of excessive IL-6 production in vivo on the development and function of Foxp3+ regulatory T cells. $\mathrm{J}$ Immunol 186:32-40

García-Gómez C, Nolla JM, Valverde J, Narváez J, Corbella E, Pintó X (2008) High HDL-cholesterol in women with rheumatoid arthritis on low-dose glucocorticoid therapy. Eur J Clin Invest 38:686-692

Gelfand JM, Neimann AL, Shin DB, Wang X, Margolis DJ, Troxel AB (2006) Risk of myocardial infarction in patients with psoriasis. JAMA 296:1735-1741

Georgiadis AN, Papavasiliou EC, Lourida ES, Alamanos Y, Kostara C, Tselepis AD (2006) Atherogenic lipid profile is a feature characteristic of patients with early rheumatoid arthritis: effect of early treatment-a prospective, controlled study. Arthritis Res Ther 8:R82

Georgiadis AN, Voulgari PV, Argyropoulou MI, Alamanos Y, Elisaf M, Tselepis AD, Drosos AA (2008) Early treatment reduces the cardiovascular risk factors in newly diagnosed rheumatoid arthritis patients. Semin Arthritis Rheum 38:13-19

Gordon SM, Davidson WS (2012) Apolipoprotein A-I mimetics and high-density lipoprotein function. Curr Opin Endocrinol Diabetes Obes 19:109-114

Graler MH, Goetzl EJ (2004) The immunosuppressant FTY720 down-regulates sphingosine 1-phosphate G-protein-coupled receptors. FASEB J 18:551-553 
Grand RJ, Ramakrishna J, Calenda KA (1995) Inflammatory bowel disease in the pediatric patient. Gastroenterol Clin North Am 24:613-632

Grinberg-Bleyer Y, Saadoun D, Baeyens A, Billiard F, Goldstein JD, Grégoire S, Martin GH, Elhage R, Derian N, Carpentier W, Marodon G, Klatzmann D, Piaggio E, Salomon BL (2010) Pathogenic $\mathrm{T}$ cells have a paradoxical protective effect in murine autoimmune diabetes by boosting Tregs. J Clin Invest 120:4558-4568

Gruaz L, Delucinge-Vivier C, Descombes P, Dayer JM, Burger D (2010) Blockade of T cell contact-activation of human monocytes by high-density lipoproteins reveals a new pattern of cytokine and inflammatory genes. PLoS ONE 5:e9418

Grunfeld C, Marshall M, Shigenaga JK, Moser AH, Tobias P, Feingold KR (1999) Lipoproteins inhibit macrophage activation by lipoteichoic acid. J Lipid Res 40:245-252

Gu X, Lawrence R, Krieger M (2000) Dissociation of the high density lipoprotein and low density lipoprotein binding activities of murine scavenger receptor class B type I (mSR-BI) using retrovirus library-based activity dissection. J Biol Chem 275:9120-9130

Gupta N, DeFranco AL (2007) Lipid rafts and B cell signaling. Semin Cell Dev Biol 18:616-626

Haas MJ, Mooradian AD (2011) Inflammation, high-density lipoprotein and cardiovascular dysfunction. Curr Opin Infect Dis 24:265-272

Haase CL, Tybjærg-Hansen A, Qayyum AA, Schou J, Nordestgaard BG, Frikke-Schmidt RLCAT (2012) HDL cholesterol and ischemic cardiovascular disease: a Mendelian randomization study of HDL cholesterol in 54,500 individuals. J Clin Endocrinol Metab 97:E248-E256

Hahn BH, Grossman J, Ansell BJ, Skaggs BJ, McMahon M (2008) Altered lipoprotein metabolism in chronic inflammatory states: proinflammatory high-density lipoprotein and accelerated atherosclerosis in systemic lupus erythematosus and rheumatoid arthritis. Arthritis Res Ther $10: 213$

Hargrove GM, Junco A, Wong NC (1999) Hormonal regulation of apolipoprotein AI. J Mol Endocrinol 22:103-111

Hassan HH, Denis M, Krimbou L, Marcil M, Genest J (2006) Cellular cholesterol homeostasis in vascular endothelial cells. Can J Cardiol 22:35B-40B

Heinecke JW (2009) The HDL, proteome: a marker-and perhaps mediator-of coronary artery disease. J Lipid Res 50(Suppl):S167-S171

Holzer M, Wolf P, Curcic S, Birner-Gruenberger R, Weger W, Inzinger M, El-Gamal D, Wadsack C, Heinemann A, Marsche G (2012) Psoriasis alters HDL composition and cholesterol efflux capacity. J Lipid Res 53:1618-1624

Hua X, Su J, Svenungsson E, Hurt-Camejo E, Jensen-Urstad K, Angelin B, Båvenholm P, Frostegård J (2009) Dyslipidaemia and lipoprotein pattern in systemic lupus erythematosus (SLE) and SLE-related cardiovascular disease. Scand J Rheumatol 38:184-189

Jafarnejad A, Bathaie SZ, Nakhjavani M, Hassan MZ (2008) Investigation of the mechanisms involved in the high-dose and long-term acetyl salicylic acid therapy of type I diabetic rats. J Pharmacol Exp Ther 324:850-857

Jamnitski A, Levels JH, van den Oever IA, Nurmohamed MT (2013) High-density lipoprotein profiling changes in patients with rheumatoid arthritis treated with tumor necrosis factor inhibitors: a cohort study. J Rheumatol 40:825-830

Jiao YL, Wu MP (2008) Apolipoprotein A-I diminishes acute lung injury and sepsis in mice induced by lipoteichoic acid. Cytokine 43:83-87

Juárez-Rojas J, Medina-Urrutia A, Posadas-Sánchez R, Jorge-Galarza E, Mendoza-Pérez E, Caracas-Portilla N, Cardoso-Saldaña G, Muñoz-Gallegos G, Posadas-Romero C (2008) High-density lipoproteins are abnormal in young women with uncomplicated systemic lupus erythematosus. Lupus 17:981-987

Jury EC, Isenberg DA, Mauri C, Ehrenstein MR (2006) Atorvastatin restores Lck expression and lipid raft-associated signaling in $\mathrm{T}$ cells from patients with systemic lupus erythematosus. $\mathrm{J}$ Immunol 177:7416-7422

Kabouridis PS, Jury EC (2008) Lipid rafts and T-lymphocyte function: implications for autoimmunity. FEBS Lett 582:3711-3718 
Kappos L, Radue EW, O’Connor P, Polman C, Hohlfeld R, Calabresi P, Selmaj K, Agoropoulou C, Leyk M, Zhang-Auberson L, Burtin P, FREEDOMS Study Group (2010) A placebo-controlled trial of oral fingolimod in relapsing multiple sclerosis. $\mathrm{N}$ Engl $\mathrm{J}$ Med 362:387-401

Kawashiri SY, Kawakami A, Yamasaki S, Imazato T, Iwamoto N, Fujikawa K, Aramaki T, Tamai M, Nakamura H, Ida H, Origuchi T, Ueki Y, Eguchi K (2011) Effects of the antiinterleukin-6 receptor antibody, tocilizumab, on serum lipid levels in patients with rheumatoid arthritis. Rheumatol Int 31:451-456

Kerekes G, Soltész P, Dér H, Veres K, Szabó Z, Végvári A, Szegedi G, Shoenfeld Y, Szekanecz Z (2009) Effects of rituximab treatment on endothelial dysfunction, carotid atherosclerosis, and lipid profile in rheumatoid arthritis. Clin Rheumatol 28:705-710

Keul P, Tölle M, Lucke S, von Wnuck LK, Heusch G, Schuchardt M, van der Giet M, Levkau B (2007) The sphingosine-1-phosphate analogue FTY720 reduces atherosclerosis in apolipoprotein E-deficient mice. Arterioscler Thromb Vasc Biol 27:607-613

Khovidhunkit W, Kim MS, Memon RA, Shigenaga JK, Moser AH, Feingold KR, Grunfeld C (2004) Effects of infection and inflammation on lipid and lipoprotein metabolism: mechanisms and consequences to the host. J Lipid Res 45:1169-1196

Kirkham BW, Wasko MC, Hsia EC, Fleischmann RM, Genovese MC, Matteson EL, Liu H, Rahman MU (2014) Effects of golimumab, an anti-tumour necrosis factor- $\alpha$ human monoclonal antibody, on lipids and markers of inflammation. Ann Rheum Dis 73:161-169

Kiss E, Seres I, Tarr T, Kocsis Z, Szegedi G, Paragh G (2007) Reduced paraoxonase1 activity is a risk for atherosclerosis in patients with systemic lupus erythematosus. Ann N Y Acad Sci 1108:83-91

Koutroubakis IE, Oustamanolakis P, Malliaraki N, Karmiris K, Chalkiadakis I, Ganotakis E, Karkavitsas N, Kouroumalis EA (2009) Effects of tumor necrosis factor alpha inhibition with infliximab on lipid levels and insulin resistance in patients with inflammatory bowel disease. Eur J Gastroenterol Hepatol 21:283-288

Lestre S, Diamantino F, Veloso L, Fidalgo A, Ferreira A (2011) Effects of etanercept treatment on lipid profile in patients with moderate-to-severe chronic plaque psoriasis: a retrospective cohort study. Eur J Dermatol 21:916-920

Levine DM, Parker TS, Donnelly TM, Walsh A, Rubin AL (1993) In vivo protection against endotoxin by plasma high density lipoprotein. Proc Natl Acad Sci USA 90:12040-12044

Liu W, Putnam AL, Xu-Yu Z, Szot GL, Lee MR, Zhu S, Gottlieb PA, Kapranov P, Gingeras TR, Fazekas de St Groth B, Clayberger C, Soper DM, Ziegler SF, Bluestone JA (2006) CD127 expression inversely correlates with FoxP3 and suppressive function of human CD4+ T reg cells. J Exp Med 203:1701-1711

Liu G, Yang K, Burns S, Shrestha S, Chi H (2010) The S1P(1)-mTOR axis directs the reciprocal differentiation of $\mathrm{T}(\mathrm{H}) 1$ and $\mathrm{T}(\mathrm{reg})$ cells. Nat Immunol 11:1047-1056

Longnecker R, Miller CL (1996) Regulation of Epstein-Barr virus latency by latent membrane protein 2. Trends Microbiol 4:38-42

Mandala S, Hajdu R, Bergstrom J, Quackenbush E, Xie J, Milligan J, Thornton R, Shei GJ, Card D, Keohane C, Rosenbach M, Hale J, Lynch CL, Rupprecht K, Parsons W, Rosen H (2002) Alteration of lymphocyte trafficking by sphingosine-1-phosphate receptor agonists. Science 296:346-349

Marchesi S, Lupattelli G, Lombardini R, Sensini A, Siepi D, Mannarino M, Vaudo G, Mannarino E (2005) Acute inflammatory state during influenza infection and endothelial function. Atherosclerosis 178:345-350

Marik PE (2006) Dyslipidemia in the critically ill. Crit Care Clin 22:151-159

Mathieu S, Dubost JJ, Tournadre A, Malochet-Guinamand S, Ristori JM, Soubrier M (2010) Effects of 14 weeks of TNF alpha blockade treatment on lipid profile in ankylosing spondylitis. Joint Bone Spine 77:50-52

Mathison JC, Ulevitch RJ (1979) The clearance, tissue distribution, and cellular localization of intravenously injected lipopolysaccharide in rabbits. J Immunol 123:2133-2143 
Matloubian M, Lo CG, Cinamon G, Lesneski MJ, Xu Y, Brinkmann V, Allende ML, Proia RL, Cyster JG (2004) Lymphocyte egress from thymus and peripheral lymphoid organs is dependent on S1P receptor 1. Nature 427:355-360

McGillicuddy FC, de la Llera MM, Hinkle CC, Joshi MR, Chiquoine EH, Billheimer JT, Rothblat GH, Reilly MP (2009) Inflammation impairs reverse cholesterol transport in vivo. Circulation 119:1135-1145

McInnes IB, Thompson L, Giles JT, Bathon JM, Salmon JE, Beaulieu AD, Codding CE, Carlson TH, Delles C, Lee JS, Sattar N (2014) Effect of interleukin-6 receptor blockade on surrogates of vascular risk in rheumatoid arthritis: MEASURE, a randomised, placebo-controlled study. Ann Rheum Dis. doi:10.1136/annrheumdis-2013-204345 (in press)

McMahon M, Skaggs BJ, Sahakian L, Grossman J, Fitzgerald J, Ragavendra N, CharlesSchoeman C, Chernishof M, Gorn A, Witztum JL, Wong WK, Weisman M, Wallace DJ, La Cava A, Hahn BH (2011) High plasma leptin levels confer increased risk of atherosclerosis in women with systemic lupus erythematosus, and are associated with inflammatory oxidised lipids. Ann Rheum Dis 70:1619-1624

Mehta NN, Yu Y, Saboury B, Foroughi N, Krishnamoorthy P, Raper A, Baer A, Antigua J, Van Voorhees AS, Torigian DA, Alavi A, Gelfand JM (2011) Systemic and vascular inflammation in patients with moderate to severe psoriasis as measured by [18F]-fluorodeoxyglucose positron emission tomography-computed tomography (FDG-PET/CT): a pilot study. Arch Dermatol 147:1031-1039

Mehta NN, Li R, Krishnamoorthy P, Yu Y, Farver W, Rodrigues A, Raper A, Wilcox M, Baer A, DerOhannesian S, Wolfe M, Reilly MP, Rader DJ, Van Voorhees A, Gelfand JM (2012) Abnormal lipoprotein particles and cholesterol efflux capacity in patients with psoriasis. Atherosclerosis 224:218-221

Messedi M, Jamoussi K, Frigui M, Laporte F, Turki M, Chaabouni K, Mnif E, Jaloulli M, Kaddour N, Bahloul Z, Ayedi F (2011) Atherogenic lipid profile in Behcet's disease: evidence of alteration of HDL subclasses. Arch Med Res 42:211-218

Miller GJ, Miller NE (1975) Plasma-high-density-lipoprotein concentration and development of ischaemic heart-disease. Lancet 1:16-19

Mor A, Planer D, Luboshits G, Afek A, Metzger S, Chajek-Shaul T, Keren G, George J (2007) Role of naturally occurring $\mathrm{CD}^{+} \mathrm{CD} 25^{+}$regulatory $\mathrm{T}$ cells in experimental atherosclerosis. Arterioscler Thromb Vasc Biol 27:893-900

Mottonen M, Heikkinen J, Mustonen L, Isomaki P, Luukkainen R, Lassila O (2005) CD4 ${ }^{+}$CD25 ${ }^{+}$ $\mathrm{T}$ cells with the phenotypic and functional characteristics of regulatory $\mathrm{T}$ cells are enriched in the synovial fluid of patients with rheumatoid arthritis. Clin Exp Immunol 140:360-367

Musabak U, Baylan O, Cetin T, Yesilova Z, Sengul A, Saglam K, Inal A, Kocar IH (2005) Lipid profile and anticardiolipin antibodies in Behcet's disease. Arch Med Res 36:387-392

Myasoedova E, Crowson CS, Kremers HM, Roger VL, Fitz-Gibbon PD, Therneau TM, Gabriel SE (2011) Lipid paradox in rheumatoid arthritis: the impact of serum lipid measures and systemic inflammation on the risk of cardiovascular disease. Ann Rheum Dis 70:482-487

Navab M, Reddy ST, Van Lenten BJ, Fogelman AM (2011) HDL and cardiovascular disease: atherogenic and atheroprotective mechanisms. Nat Rev Cardiol 8:222-232

Navarro-Millán I, Charles-Schoeman C, Yang S, Bathon JM, Bridges SL Jr, Chen L, Cofield SS, Dell'Italia LJ, Moreland LW, O'Dell JR, Paulus HE, Curtis JR (2013) Changes in lipoproteins associated with methotrexate or combination therapy in early rheumatoid arthritis: results from the treatment of early rheumatoid arthritis trial. Arthritis Rheum 65:1430-1438

Newburger JW, Burns JC, Beiser AS, Loscalzo J (1991) Altered lipid profile after Kawasaki syndrome. Circulation 84:625-631

Nofer JR, Bot M, Brodde M, Taylor PJ, Salm P, Brinkmann V, van Berkel T, Assmann G, Biessen EA (2007) FTY720, a synthetic sphingosine 1 phosphate analogue, inhibits development of atherosclerosis in low-density lipoprotein receptor-deficient mice. Circulation 115:501-508

Norata GD, Catapano AL (2012) HDL and adaptive immunity: a tale of lipid rafts. Atherosclerosis 225:34-35 
Norata GD, Callegari E, Marchesi M, Chiesa G, Eriksson P, Catapano AL (2005) High-density lipoproteins induce transforming growth factor-beta2 expression in endothelial cells. Circulation 111:2805-2811

Norata GD, Marchesi P, Pirillo A, Uboldi P, Chiesa G, Maina V, Garlanda C, Mantovani A, Catapano AL (2008) Long pentraxin 3, a key component of innate immunity, is modulated by high-density lipoproteins in endothelial cells. Arterioscler Thromb Vasc Biol 28:925-931

Norata GD, Pirillo A, Ammirati E, Catapano AL (2012) Emerging role of high density lipoproteins as a player in the immune system. Atherosclerosis 220:11-21

O'Connell BJ, Denis M, Genest J (2004) Cellular physiology of cholesterol efflux in vascular endothelial cells. Circulation 110:2881-2888

O'Neill SG, Giles I, Lambrianides A, Manson J, D'Cruz D, Schrieber L, March LM, Latchman DS, Isenberg DA, Rahman A (2010) Antibodies to apolipoprotein A-I, high-density lipoprotein, and C-reactive protein are associated with disease activity in patients with systemic lupus erythematosus. Arthritis Rheum 62:845-854

Orem A, Yandi YE, Vanizor B, Cimsit G, Uydu HA, Malkoc M (2002) The evaluation of autoantibodies against oxidatively modified low-density lipoprotein (LDL), susceptibility of LDL to oxidation, serum lipids and lipid hydroperoxide levels, total antioxidant status, antioxidant enzyme activities, and endothelial dysfunction in patients with Behcet's disease. Clin Biochem 35:217-224

Parmentier-Decrucq E, Duhamel A, Ernst O, Fermont C, Louvet A, Vernier-Massouille G, Cortot A, Colombel JF, Desreumaux P, Peyrin-Biroulet L (2009) Effects of infliximab therapy on abdominal fat and metabolic profile in patients with Crohn's disease. Inflamm Bowel Dis 15:1476-1484

Peters MJ, Vis M, van Halm VP, Wolbink GJ, Voskuyl AE, Lems WF, Dijkmans BA, Twisk JW, de Koning MH, van de Stadt RJ, Nurmohamed MT (2007) Changes in lipid profile during infliximab and corticosteroid treatment in rheumatoid arthritis. Ann Rheum Dis 66:958-961

Phillips MC (2013) New insights into the determination of HDL structure by apolipoproteins: thematic review series: high density lipoprotein structure, function, and metabolism. J Lipid Res 54:2034-2048

Pollono EN, Lopez-Olivo MA, Lopez JA, Suarez-Almazor ME (2010) A systematic review of the effect of TNF-alpha antagonists on lipid profiles in patients with rheumatoid arthritis. Clin Rheumatol 29:947-955

Prosser HC, Ng MK, Bursill CA (2012) The role of cholesterol efflux in mechanisms of endothelial protection by HDL. Curr Opin Lipidol 23:182-189

Raterman HG, Levels H, Voskuyl AE, Lems WF, Dijkmans BA, Nurmohamed MT (2013) HDL protein composition alters from proatherogenic into less atherogenic and proinflammatory in rheumatoid arthritis patients responding to rituximab. Ann Rheum Dis 72:560-565

Ridker PM, Howard CP, Walter V, Everett B, Libby P, Hensen J, Thuren T, CANTOS Pilot Investigative Group (2012) Effects of interleukin-1 $\beta$ inhibition with canakinumab on hemoglobin A1c, lipids, C-reactive protein, interleukin-6, and fibrinogen: a phase IIb randomized, placebo-controlled trial. Circulation 126:2739-2748

Rivera J, Proia RL, Olivera A (2008) The alliance of sphingosine-1-phosphate and its receptors in immunity. Nat Rev Immunol 8:753-763

Romanato G, Scarpa M, Angriman I, Faggian D, Ruffolo C, Marin R, Zambon S, Basato S, Zanoni S, Filosa T, Pilon F, Manzato E (2009) Plasma lipids and inflammation in active inflammatory bowel diseases. Aliment Pharmacol Ther 29:298-307

Ronda N, Favari E, Borghi MO, Ingegnoli F, Gerosa M, Chighizola C, Zimetti F, Adorni MP, Bernini F, Meroni PL (2014) Impaired serum cholesterol efflux capacity in rheumatoid arthritis and systemic lupus erythematosus. Ann Rheum Dis 73(3):609-615. doi:10.1136/annrheumdis2012-202914

Sala F, Cutuli L, Grigore L, Pirillo A, Chiesa G, Catapano AL, Norata GD (2013) Prevalence of classical CD $14^{++} / \mathrm{CD} 16^{-}$but not of intermediate $\mathrm{CD} 14^{++} / \mathrm{CD} 16^{+}$monocytes in hypoalphalipoproteinemia. Int J Cardiol 168:2886-2889 
Salazar A, Mana J, Pinto X, Argimon JM, Hurtado I, Pujol R (2002) Corticosteroid therapy increases HDL-cholesterol concentrations in patients with active sarcoidosis and hypoalphalipoproteinemia. Clin Chim Acta 320:59-64

Salemi G, Gueli MC, Vitale F, Battaglieri F, Guglielmini E, Ragonese P, Trentacosti A, Massenti MF, Savettieri G, Bono A (2010) Blood lipids, homocysteine, stress factors, and vitamins in clinically stable multiple sclerosis patients. Lipids Health Dis 9:19

Sappati Biyyani RS, Putka BS, Mullen KD (2010) Dyslipidemia and lipoprotein profiles in patients with inflammatory bowel disease. J Clin Lipidol 4:478-482

Sarkissian T, Beyene J, Feldman B, McCrindle B, Silverman ED (2007) Longitudinal examination of lipid profiles in pediatric systemic lupus erythematosus. Arthritis Rheum 56:631-638

Scanu AM, Edelstein C (2008) HDL: bridging past and present with a look at the future. FASEB J 22:4044-4054

Sethi A, Parmar HS, Kumar A (2011) The effect of aspirin on atherogenic diet-induced diabetes mellitus. Basic Clin Pharmacol Toxicol 108:371-377

Shah S, Casas JP, Drenos F, Whittaker J, Deanfield J, Swerdlow DI, Holmes MV, Kivimaki M, Langenberg C, Wareham N, Gertow K, Sennblad B, Strawbridge RJ, Baldassarre D, Veglia F, Tremoli E, Gigante B, de Faire U, Kumari M, Talmud PJ, Hamsten A, Humphries SE, Hingorani AD (2013) Causal relevance of blood lipid fractions in the development of carotid atherosclerosis: Mendelian randomization analysis. Circ Cardiovasc Genet 6:63-72

Shiflett AM, Bishop JR, Pahwa A, Hajduk SL (2005) Human high density lipoproteins are platforms for the assembly of multi-component innate immune complexes. J Biol Chem 280:32578-32585

Shoenfeld Y, Gerli R, Doria A, Matsuura E, Cerinic MM, Ronda N, Jara LJ, Abu-Shakra M, Meroni PL, Sherer Y (2005) Accelerated atherosclerosis in autoimmune rheumatic diseases. Circulation 112:3337-3347

Smythies LE, White CR, Maheshwari A, Palgunachari MN, Anantharamaiah GM, Chaddha M, Kurundkar AR, Datta G (2010) Apolipoprotein A-I mimetic 4F alters the function of human monocyte-derived macrophages. Am J Physiol Cell Physiol 298:C1538-C1548

Stagakis I, Bertsias G, Karvounaris S, Kavousanaki M, Virla D, Raptopoulou A, Kardassis D, Boumpas DT, Sidiropoulos PI (2012) Anti-tumor necrosis factor therapy improves insulin resistance, beta cell function and insulin signaling in active rheumatoid arthritis patients with high insulin resistance. Arthritis Res Ther 14:R141

Tardif JC, L'allier PL, Ibrahim R, Grégoire JC, Nozza A, Cossette M, Kouz S, Lavoie MA, Paquin J, Brotz TM, Taub R, Pressacco J (2010) Treatment with 5-lipoxygenase inhibitor VIA-2291 (Atreleuton) in patients with recent acute coronary syndrome. Circ Cardiovasc Imaging 3:298-307

Tedesco-Silva H, Pescovitz MD, Cibrik D, Rees MA, Mulgaonkar S, Kahan BD, Gugliuzza KK, Rajagopalan PR, Esmeraldo Rde M, Lord H, Salvadori M, Slade JM, FTY720 Study Group (2006) Randomized controlled trial of FTY720 versus MMF in de novo renal transplantation. Transplantation 82:1689-1697

Teixeira PC, Cutler P, Vuilleumier N (2012) Autoantibodies to apolipoprotein A-1 in cardiovascular diseases: current perspectives. Clin Dev Immunol 2012:868251. doi:10.1155/2012/ 868251

Terasaka N, Wang N, Yvan-Charvet L, Tall AR (2007) High-density lipoprotein protects macrophages from oxidized low-density lipoprotein-induced apoptosis by promoting efflux of 7-ketocholesterol via ABCG1. Proc Natl Acad Sci USA 104:15093-15098

Thuahnai ST, Lund-Katz S, Anantharamaiah GM, Williams DL, Phillips MC (2003) A quantitative analysis of apolipoprotein binding to SR-BI: multiple binding sites for lipid-free and lipidassociated apolipoproteins. J Lipid Res 44:1132-1142

Triantafilou M, Miyake K, Golenbock DT, Triantafilou K (2002) Mediators of innate immune recognition of bacteria concentrate in lipid rafts and facilitate lipopolysaccharide-induced cell activation. J Cell Sci 115:2603-2611 
Troitzsch P, Paulista Markus MR, Dorr M, Felix SB, Junger M, Schminke U, Schmidt CO, Volzke H, Baumeister SE, Arnold A (2012) Psoriasis is associated with increased intimamedia thickness-the Study of Health in Pomerania (SHIP). Atherosclerosis 225:486-490

Van Lenten BJ, Hama SY, de Beer FC, Stafforini DM, McIntyre TM, Prescott SM, La Du BN, Fogelman AM, Navab M (1995) Anti-inflammatory HDL becomes pro-inflammatory during the acute phase response. Loss of protective effect of HDL against LDL oxidation in aortic wall cell cocultures. J Clin Invest 96:2758-2767

van Leuven SI, Hezemans R, Levels JH, Snoek S, Stokkers PC, Hovingh GK, Kastelein JJ, Stroes ES, de Groot E, Hommes DW (2007) Enhanced atherogenesis and altered high density lipoprotein in patients with Crohn's disease. J Lipid Res 48:2640-2646

Viñals M, Bermúdez I, Llaverias G, Alegret M, Sanchez RM, Vázquez-Carrera M, Laguna JC (2005) Aspirin increases CD36, SR-BI, and ABCA1 expression in human THP-1 macrophages. Cardiovasc Res 66:141-149

Voight BF, Peloso GM, Orho-Melander M, Frikke-Schmidt R, Barbalic M, Jensen MK, Hindy G, Hólm H, Ding EL, Johnson T, Schunkert H, Samani NJ, Clarke R, Hopewell JC, Thompson JF, Li M, Thorleifsson G, Newton-Cheh C, Musunuru K, Pirruccello JP, Saleheen D, Chen L, Stewart A, Schillert A, Thorsteinsdottir U, Thorgeirsson G, Anand S, Engert JC, Morgan T, Spertus J, Stoll M, Berger K, Martinelli N, Girelli D, McKeown PP, Patterson CC, Epstein SE, Devaney J, Burnett MS, Mooser V, Ripatti S, Surakka I, Nieminen MS, Sinisalo J, Lokki ML, Perola M, Havulinna A, de Faire U, Gigante B, Ingelsson E, Zeller T, Wild P, de Bakker PI, Klungel OH, Maitland-van der Zee Zee AH, Peters BJ, de Boer A, Grobbee DE, Kamphuisen PW, Deneer VH, Elbers CC, Onland-Moret NC, Hofker MH, Wijmenga C, Verschuren WM, Boer JM, van der Schouw YT, Rasheed A, Frossard P, Demissie S, Willer C, Do R, Ordovas JM, Abecasis GR, Boehnke M, Mohlke KL, Daly MJ, Guiducci C, Burtt NP, Surti A, Gonzalez E, Purcell S, Gabriel S, Marrugat J, Peden J, Erdmann J, Diemert P, Willenborg C, König IR, Fischer M, Hengstenberg C, Ziegler A, Buysschaert I, Lambrechts D, Van de Werf F, Fox KA, El Mokhtari NE, Rubin D, Schrezenmeir J, Schreiber S, Schäfer A, Danesh J, Blankenberg S, Roberts R, McPherson R, Watkins H, Hall AS, Overvad K, Rimm E, Boerwinkle E, Tybjaerg-Hansen A, Cupples LA, Reilly MP, Melander O, Mannucci PM, Ardissino D, Siscovick D, Elosua R, Stefansson K, O'Donnell CJ, Salomaa V, Rader DJ, Peltonen L, Schwartz SM, Altshuler D, Kathiresan S (2012) Plasma HDL cholesterol and risk of myocardial infarction: a mendelian randomisation study. Lancet 380:572-580

Vuilleumier N, Dayer JM, von Eckardstein A, Roux-Lombard P (2013) Pro- or anti-inflammatory role of apolipoprotein A-1 in high-density lipoproteins? Swiss Med Wkly 143:w13781

Vuilleumier N, Montecucco F, Hartley O (2014) Autoantibodies to apolipoprotein A-1 as a biomarker of cardiovascular autoimmunity. World J Cardiol 6(5):314-326. doi:10.4330/wjc. v6.i5.314

Wang Y, Zhu X, Wu G, Shen L, Chen B (2008) Effect of lipid-bound apoA-I cysteine mutants on lipopolysaccharide-induced endotoxemia in mice. J Lipid Res 49:1640-1645

Wang SH, Yuan SG, Peng DQ, Zhao SP (2012) HDL and ApoA-I inhibit antigen presentationmediated $\mathrm{T}$ cell activation by disrupting lipid rafts in antigen presenting cells. Atherosclerosis 225:105-114

Watanabe J, Charles-Schoeman C, Miao Y, Elashoff D, Lee YY, Katselis G, Lee TD, Reddy ST (2012) Proteomic profiling following immunoaffinity capture of high-density lipoprotein: association of acute-phase proteins and complement factors with proinflammatory high-density lipoprotein in rheumatoid arthritis. Arthritis Rheum 64:1828-1837

Weigert A, Weis N, Brune B (2009) Regulation of macrophage function by sphingosine-1phosphate. Immunobiology 214:748-760

Weiss SJ (1989) Tissue destruction by neutrophils. N Engl J Med 320:365-376

Wilhelm AJ, Zabalawi M, Grayson JM, Weant AE, Major AS, Owen J, Bharadwaj M, Walzem R, Chan L, Oka K, Thomas MJ, Sorci-Thomas MG (2009) Apolipoprotein A-I and its role in lymphocyte cholesterol homeostasis and autoimmunity. Arterioscler Thromb Vasc Biol 29:843-849 
Wilhelm AJ, Zabalawi M, Owen JS, Shah D, Grayson JM, Major AS, Bhat S, Gibbs DP Jr, Thomas MJ, Sorci-Thomas MG (2010) Apolipoprotein A-I modulates regulatory T cells in autoimmune LDLr-/-, ApoA-I-/- mice. J Biol Chem 285:36158-36169

Williams HR, Willsmore JD, Cox IJ, Walker DG, Cobbold JF, Taylor-Robinson SD, Orchard TR (2012) Serum metabolic profiling in inflammatory bowel disease. Dig Dis Sci 57:2157-2165

Yatomi Y (2008) Plasma sphingosine 1-phosphate metabolism and analysis. Biochim Biophys Acta 1780:606-611

Young D, Peterson C, Basch C, Halladay SC (1995) Effects of naproxen and nabumetone on serum cholesterol levels in patients with osteoarthritis. Clin Ther 17:231-240

Yu Y, Sheth N, Krishnamoorthy P, Saboury B, Raper A, Baer A, Ochotony R, Doveikis J, Derohannessian S, Voorhees AS, Torigian DA, Alavi A, Gelfand JM, Mehta NN (2012) Aortic vascular inflammation in psoriasis is associated with HDL particle size and concentration: a pilot study. Am J Cardiovasc Dis 2:285-292

Yuhanna IS, Zhu Y, Cox BE, Hahner LD, Osborne-Lawrence S, Lu P, Marcel YL, Anderson RG, Mendelsohn ME, Hobbs HH, Shaul PW (2001) High-density lipoprotein binding to scavenger receptor-BI activates endothelial nitric oxide synthase. Nat Med 7:853-857

Yvan-Charvet L, Pagler T, Gautier EL, Avagyan S, Siry RL, Han S, Welch CL, Wang N, Randolph GJ, Snoeck HW, Tall AR (2010a) ATP-binding cassette transporters and HDL suppress hematopoietic stem cell proliferation. Science 328:1689-1693

Yvan-Charvet L, Wang N, Tall AR (2010b) Role of HDL, ABCA1, and ABCG1 transporters in cholesterol efflux and immune responses. Arterioscler Thromb Vasc Biol 30:139-143

Zapolska-Downar D, Naruszewicz M, Zapolski-Downar A, Markiewski M, Bukowska H, Millo B (2000) Ibuprofen inhibits adhesiveness of monocytes to endothelium and reduces cellular oxidative stress in smokers and non-smokers. Eur J Clin Invest 30:1002-1010 